\title{
THE UNWRITTEN HISTORY IN OUR TEXTBOOKS
}

\author{
Elena-Tereza DANCIU \\ University of Craiova, Craiova, Romania \\ tereza.danciu@yahoo.com
}

\begin{abstract}
In his book "The Dacians", Hadrian Daicoviciu showed that "only a few pages have been preserved of the great book of this people's ancient history; dozens of pages, undoubtedly among the most interesting, were lost forever and many, perhaps even more interesting, were never written by ancient authors". There is a text that keeps coming to my mind very often, especially lately, because I have noticed that there is a tendency to remove or skip several pages of our history. The mission of a historian is to try to find out the historical truth with as many pages as possible. We should not overlook, we should not mitigate anything from our past. The lost or unwritten pages of history hinder this mission, it is true, but what should we do about the pages that were written and, deliberately, are not included in the history books?
\end{abstract}

\section{Keywords: history, ancient, pages, textbooks, historical truth}

\section{The history of the Geto-Dacians - a paradox of the foreign and Romanian medieval historiography}

\subsection{Are the Geto-Dacians the ancestors of the Scandinavian peoples?}

I will never understand why we intentionally fragment historical truth. If in ancient times and the early Middle Ages, out of a religious mentality or a social mentality, or even due to historical circumstances, we allowed others to write our history, I do not know why later, the historians of Denmark, Sweden and Spain wrote proudly about Zamolxis, Deceneus or Burebista, whereas our historians started from the Roman conquest. Denmark was called Gothia, Getia or even Dacia.

In the eleventh century, a Norman chronicler wrote about "Dacia which is called Denmark at present". Its inhabitants, the Goths, had "many kings generously gifted with the science of admirable philosophies, especially Zeuta and Dichineus, and also Zamolxis, and many others".
Isidore of Seville wrote about Spain "where the glorious fecundity of the Getic genius flourished". Alfonso X el Sabio, King of Spain, wrote in his book Cronica General about Dacia or Gothia, about Zamolxis who "was greatly wise in philosophy", about "Boruista" and "Dicineo" [1].

Another work called Zamolxis - primul legiuitor al gețilorl 'Zamolxis - the first legislator of the Gets', published in 1687, belonged to Carolus Lundius, professor of legal sciences and municipal judge. In this paper, the author considered that the Dacians were the ancestors of the Swedes. From Carolus Lundius we also find out that: "it must be clear to all, that those which the ancients called with great veneration the Gets, were later called by writers, by a unanimous agreement, the Goths" [2]. We see, in other words, that in the Middle Ages there was a whole literature throughout Europe about the Geto-Dacians who were the ancestors of all, except us. Our ancestors were the Romans, our origin was Roman, and we ignored the ancient Geto-Dacian roots. 


\subsection{Why have the Geto-Dacians been ignored in the Romanian historiography?}

Maybe our chroniclers, Grigore Ureche and Miron Costin, educated at Jesuit colleges in Lviv, Bar and Cameniţa in Poland, fascinated by Roman culture and learning the Latin language, were more inclined to say that: "The Romanians living in the Hungarian Country and Transylvania and Maramuress, have the same origin as the Moldavians and they are all the descendants of Rome" [3]. Or to state that: "The beginning of these countries and people living in Moldavia and Wallachia and also in the Hungarian Countries with this name Romanians until today ... they are all a nation and have the same origin ... from Trajan the king of Rome, with some hundred years over one thousand ..." [4].

Perhaps the representatives of the Transylvanian School, out of the wish to be no longer considered a tolerated nation, started our history from the Roman conquest. A people with a noble origin would not have deserved such treatment.

This permanent inferiority complex leads us to ignore them, to scorn those who lived here before the Roman conquest. And we wonder then, trying, indignantly, to find arguments to combat the immigration theory supported by Robert Roesler and his followers.

Those who settled around us, those who tore pieces of the territory we inhabited are much interested in writing that the Dacians perished after the Roman conquest or that the population who lived in the province of Dacia migrated to the south of the Danube around 271, returning home a thousand years later. But why were or are we interested in getting the Dacians out of history, especially after December 1989 ?

The Dacians, not the Romans are the binder of our continuity in this space. They managed, long ago, to found a state, they were considered by Herodotus "the bravest and most righteous of the Thracians", they had doctors appreciated even more than the Greek doctors, they were the creators of a philosophical and religious view which was very close to the Christian one.

We needed about two thousand years before we established a state whose boundaries were close to those of the Geto-Dacian state led by Decebalus. We discover the bravery of our ancestors in crucial moments. Romanian medicine has been pioneering in some fields. We have doctors who have preserved the traditional spirit, but they distinguish themselves abroad rather than home.

\subsection{The ancient history of our nation through the eyes of foreigners}

Regarding Thraco-Dacian medicine there is a text of Plato's Dialogues that Ana Blandiana mentions in an article written in the 1990s. This article tells us about a trip from Bucharest to Oradea taken by Romanian and British writers. In a museum in Oradea, there was this text of Plato on an inscription: "The Thracian doctors are superior to our Greek doctors, because before they heal the body, they seek to take care of the soul ... It is the same, Carmide, with this spell. I learnt it there in the army, from a Thracian doctor, one of the disciples of Zamolxis, who, they say, makes people immortal. This Thracian said that Greek doctors were right to speak as I have just shown you. But Zamolxis, he added, our king, who is a god, tells us that, as we should not try to treat an eye without taking care of the head, so the head cannot be treated without taking care of the body. So we must take care of the body along with the soul. This is why Greek doctors know little about most diseases: because they do not know the whole they have to take care of. If the whole is sick, the part cannot be healthy. For, they said, all good and bad things - for the body and for man as a whole - come from the soul and from there they flow, as from head to eye, my friend, he said, the soul can be healed with spells. 
These spells are the beautiful words that make wisdom be born in the soul".

The British writers were impressed when they heard that the Thraco-Dacian doctors were known and appreciated in ancient Greece and that Plato wrote about us. Their reply was: "If Plato had written about the Scots, we would have put the sentence on the flag".

We are surprised to find out that foreigners who begin to know us better, appreciate us much more than we do. Ana Blandiana's conclusion was that we didn't even introduce that text in our history books, not to mention the flag [5].

\section{The role and place of history in the Romanian post-communist society}

While learning and teaching the history of Romanian law, I tried to find arguments and see why in Romanian historiography, we were attached to the Roman past rather than to the native Dacian one, why we focused on our Roman roots and only after Haşdeu wrote the famous article: "Have the Dacians perished?" did we begin to turn our attention to the history preceding the Roman conquest.

But I fail to find any reason why today, when living in a democratic society, free from censorship, we are unable to write a history that does not fragment or avoid historical truth. However, I can see the effects of incomplete history textbooks. With few exceptions, young people today no longer know or know only part of the history of the country where they were born.

The question is what will the destiny of a nation be if that nation does not know its history, losing its traditions and faith? I'm not a historian, I am a jurist, but I would like the authors of such books to give us an answer. I personally learnt more history from the blamed textbooks written under the communism than I could learn from the current textbooks. I will try to make a brief analysis.
First there is a reduction in the number of history hours. The reason is to simplify the curriculum. The students of my generation studied the history of the Romanians in the fourth grade, in the eighth grade, then in high school in the ninth and tenth grade. Today in high school, they study the history of the Romanians in the twelfth grade, one hour a week or 2-3 hours a week in specialized high schools.

I read $12^{\text {th }}$ grade history textbooks to find out what kind of history of their own country the students of today learn, and what kind of history I would have learnt if I had been a student. Reading some textbooks, I would not have realized whether I was studying the history of the Romanians or the history of another people, because it is simply written on the books: "History". Perhaps it will be worse if it is written: "Education for society", as suggested not long ago. Confusion will deepen. Students will not know whether they learn the history of their country or of another country, and moreover, they will not know whether they learn history or another discipline.

Opening the books and reading the contents, I found out that some of them had given up chronology and made a sort of history by five themes: "Historical spaces and peoples", "People, society and the world of ideas", "State and politics", "International relations", "Religion and religious life". If it were about a journal, a book of studies or essays, there would be no problem, but it is a history textbook where a chronological criterion must exist. Otherwise, we might confuse the Antiquity with the Middle Ages and the Middle Ages with modern times, a tendency that I notice in young people today. Frankly, I doubt that even those who already have a set of historical notions can understand much. There is a loss of track, of the logical sequence of ideas, of data and facts.

\section{Why do we start history from the Roman conquest again?}


The saddest thing is when we see a truncated history, in which, out of time and space economy, we decide who deserves to be entered or not in the nation's book of history.

I still wonder what did our ancestors, the Dacians, do wrong so that repeatedly, intentionally or not, we forgot to write about them? Didn't they deserve it because they were part of the barbarian world or we tend to write about conquerors and we forget the conquered ones? The history of mankind begins in a period preceding the primitive communal system, and it is our duty to expose any information about us, either written or unwritten. The history of a people is its DNA, in which no chromosomal link should be omitted. Any deformation, any deviation leads to illness.

A sick society is a society which does not know and does not respect its history, traditions and can no longer appreciate true values. Such a society, sooner or later, is likely to perish and, when one is in the precipice, one has no longer much of a chance to discover who is responsible.

But beyond history textbooks, alternative or not, censored or not, written for political or social reasons, every Romanian should know that the roots of this nation start from the Thraco-Geto-Dacians or even from the Pelasgians, as we read in Bulgarian history books or on inscriptions in Bulgarian museums.

They should know that they were not so barbaric as we might have thought, as long as the ancient Greek and Roman authors wrote about the philosophical and religious doctrine of Zamolxis or Thraco-Dacian medicine. Moreover, between the $1^{\text {st }}$ century $\mathrm{BC}$ and the $1^{\text {st }}$ century $\mathrm{AC}$, the Geto-Dacian society bloomed. Evidence of economic development and political maturity is the establishment of the Dacian state.

In addition, the conquest of Dacia was a significant event for Roman history. The Dacians were hard to conquer and the province of Dacia was the last territory annexed to the borders of the Roman Empire. One of the beneficial effects of the conquest of Dacia by the Romans was the economic recovery of the Empire. The 165,500 kilograms of fine gold and 331,000 kilograms of silver brought to Rome by Trajan determined him to organize festivities and games for 123 days. A year later, the Roman citizens did not pay taxes and Trajan ordered the building of the great Forum, the Column and the monument of Adamclisi.

The Romanians living in Italy and those visiting Rome should know that they can see the statues of our Dacian ancestors on the triumphal arch. On the arch in Thessaloniki one can also see Dacian soldiers who were part of the Roman army. The Dacian men did not die after the conquest, on the contrary, they were part of the Roman army, forming legions or auxiliary troops called "Getica" or "Dacica". Some of the Dacian slaves brought to Rome became gladiators and due to their bravery they were set free.

Traces of the Dacians have been recently discovered in excavations in Germany and Poland: bracelets, weapons, pottery. And in many museums around Europe and the USA there are numerous statues of Dacians, as we learn from the $\mathrm{PhD}$ thesis of Leonard Velcescu, defended at the Sorbonne in the field of art history.

All these examples are arguments that should make us be proud of our GetoDacian ancestors and not get them out of history books and textbooks.

Perhaps our history should be a history of the values which should help us give up the permanent inferiority complex and learn the meaning of appreciation for what we had and still have good and beautiful in our country.

\section{Conclusions}

I started this brief analysis from the text of Hadrian Daicoviciu who wrote that there 
were many pages missing from the book of our ancient history. It is true! They are missing because, for a long time, we had an unwritten culture and there were others who wrote about us. But why, when we started writing our history, did we omit pages? There was and still is a trend that I personally fail to understand. I have tried to find arguments for our chroniclers and for the representatives of the Transylvanian School, but I cannot find any argument for the authors of textbooks at present. Why, for reasons of systematization and modernization of the curriculum, do we renounce important pages of our history? Why do we simplify history starting with the title? "History of the Romanians" must remain "History of the Romanians" and not "History". We also need to maintain chronological criteria to avoid confusion between periods. In addition, our historians should know that every page of our history must be written. Otherwise, how could we know ourselves, how could we appreciate our values, how could we learn from mistakes, and what will our future be if we get separated from the past?

What seems paradoxical to me is that, when we started our history books from the Roman conquest, foreigners were proud of their Geto-Dacian ancestors. Why aren't we proud of them and why don't we try to find out why other peoples considered the GetoDacians their ancestors? Is it simply a confusion between the Getae and the Goths? Or are there other reasons as well? On the other hand, I keep wondering, like our poet Ana Blandiana, when I see how we look through the eyes of others. Why are some foreigners more Romanian than we are? The answer stems from education and the appreciation of values. The answer stems from the pages of history that we should not ignore and, if we did not write them, let's start writing them now!

\section{References}

[1] Ovidiu Drimba, Istoria culturii şi civilizaţiei, Bucureşti, Editura Saeculum-Vestala, 2000, pp. 378-380.

[2] Carolus Lundius, Zamolxis - primul legiuitor al geţilor, Bucureşti, Editura Axa, 2002, p. 5.

[3] Grigore Ureche, Letopiseţul Ţării Moldovei, in Alexandru Piru, Literatura română veche, Ediţia a II-a, 1962, p. 109.

[4] Miron Costin, De neamul moldovenilor din ce ţară au ieşit strămoşii lor, in Opere alese, Bucureşti, Editura Tineretului, 1965, p. 217.

[5] Dumitru Bălaşa, Ţara soarelui sau istoria Dacoromâniei, Bârda, Editura Cuget Românesc, 2009, pp. 307-308. 